\title{
Blood purity and scientific independence: blood science and postcolonial struggles in Korea, 1926-1975
}

\author{
Jaehwan Hyun \\ Max Planck Institute for the History of Science, Berlin, Germany \\ Email: jhyun@mpiwg-berlin.mpg.de
}

\begin{abstract}
Argument
After World War II, blood groups became a symbol of anti-racial science. This paper aims to shed new light on the post-WWII history of blood groups and race, illuminating the postcolonial revitalization of racial serology in South Korea. In the prewar period, Japanese serologists developed a serological anthropology of Koreans in tandem with Japanese colonialism. The pioneering Korean hematologist Yi Samyŏl (1926-2015), inspired by decolonization movements during the 1960s, excavated and appropriated colonial serological anthropology to prove Koreans as biologically independent from the Japanese. However, his racial serology of Koreans shared colonial racism with Japanese anthropology, despite his anti-colonial nationalism.
\end{abstract}

Keywords: race; blood groups; racial serology; decolonization movements; scientific nationalism; South Korea

\section{Introduction}

In 1969, prominent South Korean hematologist Yi Samyŏl (李三悅, 1926-2015) published an article on blood-group research to prove Koreans' "blood purity" (純血) and to contend "scientific independence” (科學的自主性) (Yi 1969, 57). ${ }^{1}$ In this paper, he surveyed the blood-group distribution of Koreans, including state-of-the-art blood-group systems like the Diego antigen system. ${ }^{2}$ Based on his intensive research, Yi proudly claimed, "Koreans are a racially homogeneous nation (單一民族) and have not been mixed with the blood of neighboring ethnic groups," while the Chinese and the Japanese were “a mongrel race (雜種) whose blood is mixed" or "a racially mixed nation” (混合民族) (ibid., 64). ${ }^{3}$ At the same time, Yi contended that Korean scientists would have to achieve scientific independence from Japan and the United States in order to establish Koreans as biologically independent from the Japanese. In their international scientific reports at that time, Japanese scientists still subsumed Koreans under the Japanese, as argued for by Japanese assimilationists during the Japanese colonial rule of Korea (Yi 1969, 57).

${ }^{1}$ I adopt the McCune-Reischauer and the Revised Hepburn systems as the Romanization of Korean and Japanese; all Korean and Japanese names in this article are listed in the order of surname first, followed by the given name. Also, South Korea is labeled "Korea," except for quotations and contexts in which North Korea is mentioned.

${ }^{2}$ Human blood group systems are systems in the human species that cell-surface antigens on red blood cells are controlled by allelic or closely linked homologous genes on the same chromosome. The ABO blood group system was first discovered in 1900 and the MNS antigen system was the second in 1927. Since then, thirty-five human systems have been identified and the Diego antigen system was among them. The Diego system was discovered in 1953 and was well known for the fact that the Diego $^{\mathrm{a}}$ antigen was mainly found among East Asians and Native Americans.

${ }^{3}$ It is hard to say that all medical and biological scientists in Korea agreed with Yi Samyŏl's approach. Population geneticists in Korea did not accept the idea of "purity" and investigated the "clinical orientation" of genetic frequencies among the Chinese, Koreans, and the Japanese, despite framing Koreans as a reproductively isolated population or genetically homogeneous group (Hyun 2018).

(C) The Author(s) 2019. This is an Open Access article, distributed under the terms of the Creative Commons Attribution licence (http:// creativecommons.org/licenses/by/4.0/), which permits unrestricted re-use, distribution, and reproduction in any medium, provided the original work is properly cited. 
Historians of science have examined the ways in which blood groups were mobilized to advance various political agendas during the twentieth century. In 1910 Ludwik Hirschfeld (1884-1954) used the ABO blood-group frequencies of different national and racial groups for anthropological purposes, resulting in serological anthropology - classifying human races based on $\mathrm{ABO}$ blood groups - becoming intertwined with imperialist and nationalist politics during the interwar period. ${ }^{4}$ Due to anti-racist politics after World War II, the use of blood groups for anthropological purposes was at its height. Blood groups were refashioned into a symbol for population genetics defeating racial anthropology. ${ }^{5}$ British hematologist Arthur Mourant (1904-1994) promoted collecting information on the geographic distribution of blood groups among human populations on a global level, contending its "merit of providing criteria far removed from the traditional marks of race” (Bangham 2014, 74). In the United States, William C. Boyd (1903-1983), an immunochemist with the Boston University School of Medicine, similarly tried to use the genetic frequencies of diverse blood groups among human populations to create a more flexible racial classification that could overcome scientific racism. ${ }^{6}$ Many serologists and geneticists in developing countries in Asia and Latin America joined this global enterprise of blood-group anthropology.

This article adds to the literature on the history of the political intertwining of blood-group research before and after WWII. In particular, this study gives attention to how serological racial anthropology first developed during the colonial period and was then revitalized in a newly independent country in the context of decolonization. ${ }^{8}$ In a recent review of the colonial history of science and postcolonial science studies, Suman Seth points out that the postcolonial afterlife of colonial science and medicine has remained unexamined (Seth 2017). Taking the case of Yi Samyŏl's blood-group research in Korea from the 1950s to the 1970s, I will reveal how a postcolonial Korean scientist reinvented Japanese colonial serological anthropology as an "anti-colonial" science combatting the Japanese neo-colonial threat. During the imperial period, a Japanese serologist, Furuhata Tanemoto (古畑種基, 1891-1975), promoted serological anthropology in order to establish the uniqueness and superiority of the Japanese race, assuming the blood purity of his people. Yi, who had developed the idea of "scientific independence" in the context of democratic

\footnotetext{
${ }^{4}$ On the Hirschfeld's work, see Mikanowski (2011). Gannett and Griesemer (2004) also briefly examine the philosophical limitations of the Hirschfelds racial classification based on blood groups. Schneider (1995) offers an overview of the history of blood-group research before WWII. There are also several detailed studies of blood-group research in European countries during the interwar period. Kevles (1995) examines "reformed" eugenicists' use of blood-group data against traditional eugenics in the United Kingdom. Mazumdar (1996) shows how blood-group genetics was initiated as the first quantitative genetics in Germany. Boaz (2012) explains the way in which blood-group research was marginalized in Nazi Germany, despite Nazi's rhetoric of "blood and soil." Turda (2010) also introduces the case of the nationalistic use of serological anthropology in Hungary and Romania before WWII.

${ }^{5}$ Lipphardt (2014) offers a counter-narrative by revealing the prewar interest in the isolated group and the postwar use of anthropometry in the field of human heredity.

${ }^{6}$ On the history of Boyd's work and the boom of blood-group studies in U.S. physical anthropology in the post-WWII period, see Marks (1996) and Silverman (2000).

${ }^{7}$ Mukharji (2014) describes the history of serological anthropology and its engagement with South Asian identity politics in India before and after WWII. Wade (2017) provides an overview of blood-group research in Latin American countries, while de Souza and Santos (2014) offer a detailed explanation of blood-group research in Brazil. All of them emphasize the role that the international collaboration with the U.S. anthropologists and geneticists played in leading scientists in developing countries to be skeptical of racial serology.

${ }^{8}$ Historians of science, technology, and medicine in Korea have investigated how Japanese colonial discursive practices persisted in Korea after WWII despite the US-led reformation of science and medical education and research. Mizuno et al. (2018) seeks the transformation of Japanese colonial development in transport and power infrastructure into the Cold War technical and medical aid in Asia. Hyun (2017) and Jung and Kim (2017) reveal how colonial networks between Japanese and Korean scientists were reconstructed and reconnected in the new Cold War context, while Kim (2016) shows how a Korean physical anthropologist trained in colonial medical institutions recycled colonial knowledge for nationalist purposes. In addition, Kim (2017) illuminates the Korean state's eugenic control of disability as being similar to that of the colonial government.
} 
and decolonization movements in the 1960s, co-opted Furuhata's serological anthropology to conceive of Koreans a pure-blood race. I will show that, despite its "anti-colonial" use, Yi's bloodgroup research ultimately came to share colonial serological anthropology's racism. Throughout this study, I will demonstrate that racial serology's employment of the concept of blood purity reemerged in the context of the postcolonial struggle in Korea during the late 1960s, when most historians have acknowledged the general decline of racial serology. ${ }^{9}$

This article consists of three sections. In the first section, I examine how different research projects in serological anthropology were advanced in mainland Japan and colonial Korea in tandem with Japanese colonialism during the imperial period. It will also discuss how a specific version of serological anthropology, conducted only in mainland Japan, survived after WWII. In the second section, I investigate the demolition of serological anthropology and the "Americanization" of blood-group research in Korea after its liberation from Japan. In this section, I describe the local process of the development of blood-group research for clinical purposes after the Korean War, and the role U.S. assistance played in this. In the final section, I trace Yi's research transition from hematological studies for blood bank management to the racial serology of Koreans in the context of his engagement with postcolonial struggles in Korea.

\section{Serological anthropologies for Japanese colonialism}

The Empire of Japan was one of the leading nations in global blood-group research in the prewar period (Schneider 1995, 91). It was the empire's physicians and medical researchers in the field of forensic medicine that led to the growth of blood-group research. While physical anthropologists in the field of anatomy limited their methodology to anthropometrics, and clinicians did not institutionalize hematology and transfusion medicine in imperial Japan until the mid-1930s (Hyun 2015), Japanese forensic scientists expanded their interest in blood groups as forensic identification markers to include serological anthropology (Furuhata 1931). Their research focus was to collect information regarding ABO blood-group distribution around the empire. Following colonization of Korea through the Japan-Korea Annexation Treaty in 1910, Koreans became the main research subjects for these surveys. From the mid-1920s, scientific practitioners in medical education institutions in colonial Korea and research institutions in mainland Japan began to report on $\mathrm{ABO}$ blood-group distribution in the Korean peninsula.

Japanese medical researchers collected the ABO blood group distribution to determine "a biochemical race-index" (人種指數 or 人種係數) of multiple ethnic groups in the empire. In 1919, the Polish serologist couple Ludwik and Hannah Hirschfeld suggested that the proportion of ABO blood groups in a population varied according to racial origins, and they formulated a scheme called the biochemical race index. Based on their ABO blood-group data and the biochemical index - the proportion of Type A to Type B blood - the Hirschfelds divided the human species into three biochemical races: European, Intermediate, and Afro-Asiatic types (Hirschfeld and Hirschfeld 1919). ${ }^{10}$ In 1925, the American hematologist Reuben Ottenberg attempted to classify human races worldwide into six racial types by revising the biochemical index in consideration of the proportion of Type $\mathrm{O}$ blood in a population: European, Intermediate, Hunan, IndianManchurian, African-South Asian, and Pacific-American types (Ottenberg 1925, 1393-1395). This biochemical race index underlined the racial hierarchy between the European type, having the highest proportion of Type A blood, and the Pacific-American type, having the greatest percentage of Type B (Marks 1994, 62).

\footnotetext{
${ }^{9}$ Historians of blood-group research in the postwar period contend that racist arguments based on blood-group data disappeared in the field of blood-group genetics around the 1960s, although the race concept remained intact in terms of "population" (Mukharji 2014; Radin 2014; Marks 2012).

${ }^{10}$ They supposed that Type A blood was dominant in Europe, while Type B blood was more widely spread in Asia and Africa (Hirschfeld and Hirschfeld 1919, 679).
} 
Although most forensic scientists in mainland Japan and colonial Korea were Japanese scholars, their motivations for collecting Korean blood group data varied. Roughly speaking, the old generation of scholars in mainland Japan were devoted to proving racial superiority and the uniqueness of the Japanese people in the East Asian context, while young serologists in colonial Korea paid more attention to the racial affinity between the Japanese and other ethnic groups in the empire. The comparison between Furuhata Tanemoto in mainland Japan and Satō Takeo (佐藤武雄, 1897-1959) in colonial Korea shows this difference well. Both were students of Mita Sadanori (三田定則, 1876-1950), the first Japanese serologist in the Department of Legal Medicine at Tōkyō Imperial University Medical College. ${ }^{11}$ They were also both members of the Japanese Association of Legal Medicine (日本犯罪学会) and published their blood group research in the association's journal. Most of all, they were the only Japanese serologists to show a deep interest in the racial relations between Koreans and Japanese and they collected blood-group data from Koreans over a decade throughout the colonial period. ${ }^{12}$

Since the 1920s, Furuhata Tanemoto and his coworkers had comprised a major research group in mainland Japan. Furuhata graduated from Tōkyō Imperial University Medical College in 1916 and became the first professor of forensic medicine at Kanazawa Medical College in $1924 .{ }^{13} \mathrm{He}$ was already a well-known pioneer for his discovery of the mechanism of the inheritance of ABO blood groups in 1927, independent of Felix Bernstein's discovery in 1924 (Mazumdar 1996, 629). Furuhata's achievement in blood-group research there allowed him to become the full professor of his alma mater in 1936, in succession to Mita Sadanori.

Furuhata devoted most of his attention to revising and developing a race index based on blood group and fingerprinting data. At the Third Pan-Pacific Scientific Congress held in Tokyo in 1926, Furuhata challenged Ottenberg's classification by arguing for the replacement of the Hunan type with the Japanese type. Furuhata identified the ABO blood types of 22,313 test subjects: Japanese, Koreans, Taiwanese natives, Ainu, and Manchurian tribes (Furuhata and Kishi 1928, 2416). Through this survey, Furuhata concluded that "the Japanese have a distinct blood-group type quite different from those of all other races examined," and that the Japanese were part of the Hunan type. According to him, the Hunan type had to be replaced with the Japanese type because "the Japanese are the representative of this type" (Furuhata and Kishi 1928, 2416-2417). In Ottenberg's racial typological classification, the Hunan type was the third of six racial types and Furuhata wanted to locate the Japanese as the first in this third type (see Fig. 1).

Furuhata believed that he could demonstrate that the Japanese were the highest in the East Asian racial hierarchy and equally their biological proximity to European races. He demonstrated this through much more diligent quantitative research on blood-group data than that which had already been conducted by Western scientists. He emphasized that "Japan is serologically the best-investigated land in the world," and that Japan's scientific achievement in serology merited the placement of "the Japanese type" in racial classifications based on serological research (ibid., 2416-2417). This faith in the value of serological research led him to eagerly collect ABO bloodgroup research articles published in Japan and present his collection of blood-group data and the biochemical race index of the Japanese Empire at the Fifth Pan-Pacific Scientific Congress in British Columbia in 1933. His study was based on a blood group survey of 320,356 research subjects, including 296,140 Japanese and 11,055 Koreans. Although the collection of the literature on

\footnotetext{
${ }^{11}$ When Furuhata worked as Joshu (助手), Satō entered as Mita's freshmen student. Furuhata flew to Europe for overseas training one year before Satō's graduation. Although Mita's department was crowded with one hundred research students, Furuhata kept close relations with junior students including Satō (Miki 1976, 106-108; Furuhata and Furuhata 1976, 227). It seems that such close relations prevented them from criticizing each other's differing conclusions on serological affinity between Japanese and neighboring groups.

${ }^{12}$ Matsuda (1994) introduced Satō's blood-group research on Koreans as the only alternative for Furuhata's interpretation to the relations between Japanese and Koreans.

${ }^{13}$ Furuhata took the professorship of Kanazawa Medical College on condition of overseas training and studied in Berlin University in 1924 and 1926 (Furuhata and Furuhata 1976).
} 


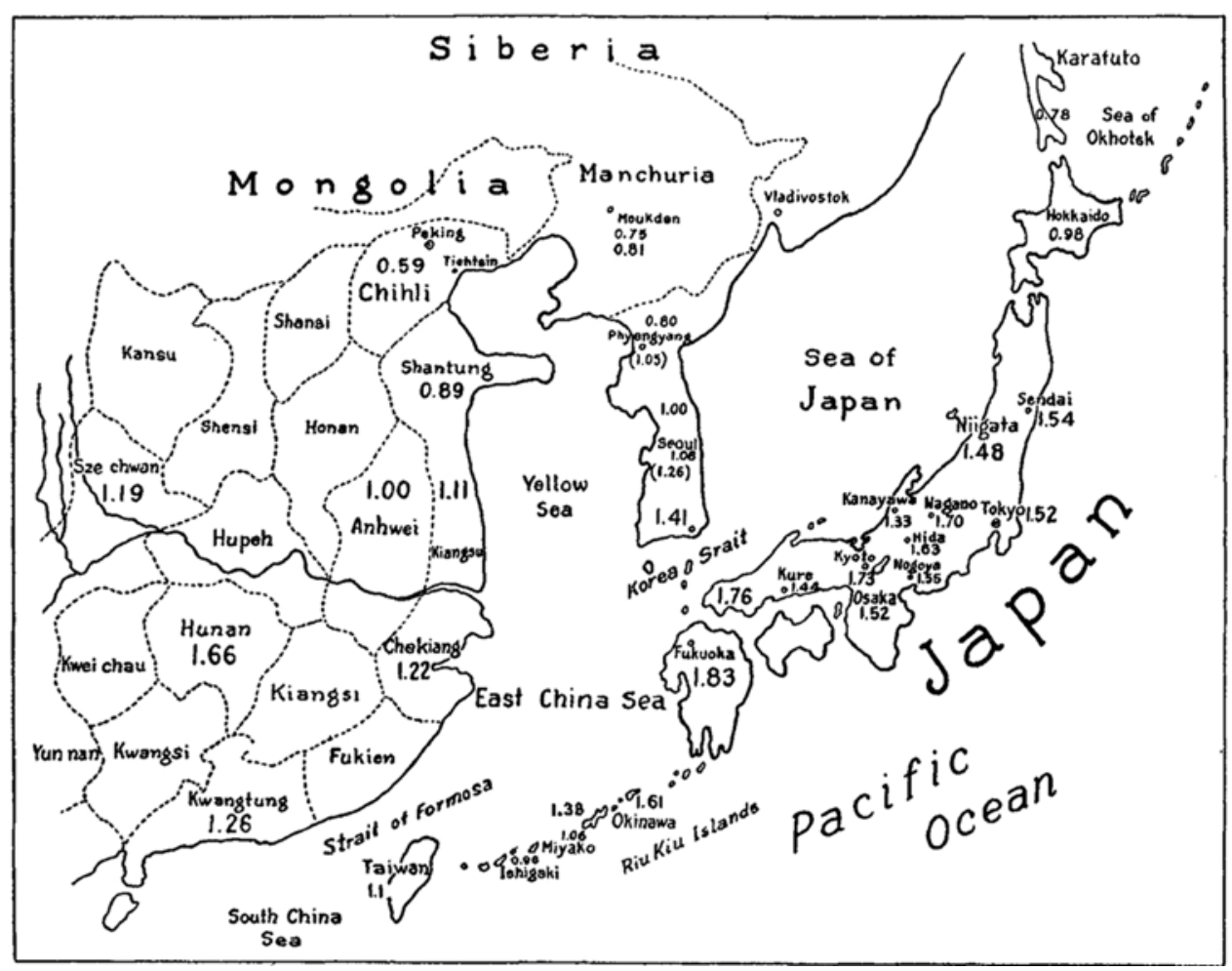

Figure 1. The Distribution of Biochemical-Race Index in the Empire of Japan in 1926 (Source: Furuhata and Kishi 1926, 86).

blood groups in Japan from 1916 to 1933 became the backbone of the database, Furuhata's team significantly contributed to the vast volume of Japanese data by sampling 6,862 parents with their 3,636 children, 82,429 soldiers of the Imperial Japanese Army and Navy, 3,218 newborn infants, and 384 human fetuses in Japan (Furuhata 1933).

During this period, he was convinced that his blood-group research could contribute to the vital anthropological question of racial classification. In 1935, Furuhata announced a "new" anthropology, “serological anthropology” (血清学的人類学), as distinctive from cultural and physical anthropology (Furuhata 1935). Furuhata argued, in contrast to the prevailing thought in physical anthropology at the time, that "the Japanese race was formed in the Japanese archipelago (日本列島) without the influence of neighboring regions like the Korean peninsula." He claimed that the distribution of $\mathrm{ABO}$ blood groups in the population living in the Japanese archipelago showed a "serological homogeneity," and that the blood-group distribution in the Japanese and neighboring groups in the Korean peninsula showed no serological connection (Furuhata 1935, 100-101). ${ }^{14}$

In contrast to Furuhata's search to distinguish the Japanese type from neighboring ethnic groups in the empire, in colonial Korea a young serologist Satō Takeo tried to look into the similarities between Japanese and Koreans. Satō graduated from Furuhata's alma mater in 1922 and in

\footnotetext{
${ }^{14}$ Furuhata was not alone in claiming the ethnic purity of the Japanese, even though the position was marginal throughout the imperial period. Hasebe Kotondo (長谷部言人, 1882-1969), professor of physical anthropology at Tōkyō Imperial University also supported the idea that the modern Japanese were only derived from an indigenous population living in the Japanese archipelago (Oguma 2002; Nanta 2008, 31-32).
} 


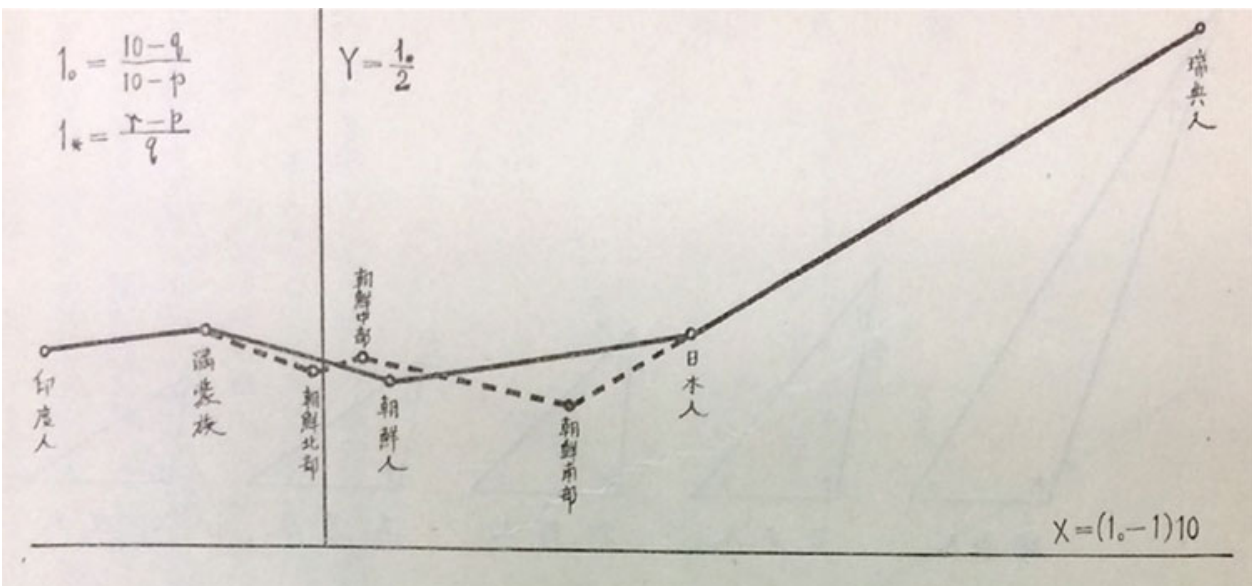

Figure 2. The racial proximity between the Japanese and neighboring groups (From left to right: Indians, Tungus, northern Koreans, middle Koreans, Koreans, southern Koreans, the Japanese, and Swedes; p, q, and r, are genetic frequencies of A, B, and O) (Source: Satō et al. 1935, 701).

1929 he took a position as professor of forensic medicine at Keijō Imperial University Medical School in colonial Korea (Keiō Gijuku 1958, 675).

Satō and his fellow serologists in colonial Korea conducted a comprehensive blood-group survey on the Korean peninsula from 1931-1934. ${ }^{15}$ They collected ABO blood-group data from 24,929 Koreans during their research. In 1935, they reported the biochemical race index of Koreans using the ABO blood-group data that they had collected. They divided the blood-group distribution of Korea into three local regions (northern, middle, and southern); the race index of northern Koreans was 0.99 , that of middle Koreans was 1.05 , while southern Koreans' race index was 1.25. According to Ottenberg's classification, northern and middle Koreans were of the IndiaManchurian type and southern Koreans were the Hunan type, which Furuhata wanted to rename the "Japanese type" (Satō et al. 1935).

Satō Takeo understood this clinal pattern from the northern region of Korea to the Japanese archipelago as proof of biological similarity between the Japanese and Koreans: "this study [of blood groups in Koreans] can be persuasive scientific evidence that indicates a close and inseparable relationship between Japanese, Koreans, Manchurians, and Mongolians in terms of anthropology" (ibid., 53; see Fig. 2). From 1934 on, Satō's group at Keijō pursued a blood-group survey of Manchurians and Mongolians in the region of Manchuria. In 1943, using the ABO blood-group data of 3,019 Mongolians and Manchurians, Satō hypothesized the migration history of ethnic groups within the empire and their biological proximity based on the blood group data. Sato explained: "the difference of the race index between Manchurians and Northern Koreans is remarkably timid. There is a certain relationship between Mongolians, Manchurians, and Koreans and the incremental transition is observed in the race index among them. [Meanwhile,] the blood group distribution of Kyoto and Nara Prefecture is so close to that of Southern Koreans" (Satō 1943, 418).

In this context, Furuhata and Satō reached different conclusions about the serological relations between the Japanese and Koreans. Furuhata believed that Koreans were considerably different from the Japanese as well as being ethnically heterogeneous; the higher ratio of the race index in southern Koreans is just a historical contingency of intermarriage between the Japanese and

\footnotetext{
${ }^{15}$ For the colonial history of serological anthropology at the Institute of Legal Medicine of Keijō Imperial University Medical School, see Jung (2012). His work deals with Satō Takeo's serological research activity in detail.
} 
Koreans in the southern peninsula; Koreans had not influenced the purity of Japanese blood. According to Furuhata, even though Koreans could have impacted the blood-group distribution of the Japanese in the prehistoric period, the two ethnic groups had now become biologically different (Furuhata 1935, 100-101). He didn't change his view when he cited Satō's Korean blood group data (Furuhata 1941). In contrast, Satō discovered the clinal relationship among Manchurians, (northern and southern) Koreans, and the Japanese. Satō supposed a strong serological connection between the Japanese and Koreans, although he did not criticize Furuhata's interpretation explicitly (Satō 1943, 418).

Conflicting conclusions about the biological closeness of the Japanese and Koreans reflected different research interests relating to two different sides of Japanese colonialism. First, the Empire of Japan used its cultural and biological similarities to the natives of certain regions in East Asia to justify their colonization. Notably, following nationwide Korean resistance against Japanese colonial rule in March 1919, the colonial government in Korea actively promoted assimilation. A theory of Japanese historian Kita Sadakichi (喜田貞吉, 1871-1939) about the common ancestry of the Japanese and Koreans (日鮮同祖論) became a foundation for justifying this assimilation policy and criticizing the Korean independence movement (Kang 1997, 53-57). This thesis posited common traits in blood, culture, and language between the Japanese and Koreans dating back to ancient times. Further, the colonial government propagated a compulsory assimilation policy of Japanese and Korean unity (内鮮一体) to mobilize Koreans to fight after the outbreak of the Second Sino-Japanese War in 1937 (Shin 2006, 44).

At the same time, in certain other contexts Japan favored differentiation between the Japanese colonizer and the colonized Asians, as racism was the underpinning of colonial rule in Korea and Taiwan. According to such colonial racism, Koreans were defined as an inferior race that required guidance from the superior Japanese race to achieve "civilization and enlightenment" (Shin 2006, 42). Academic efforts to differentiate the Japanese race from the races they had colonized emerged more explicitly from the 1930s onwards. As a result of colonial assimilation policies in Taiwan and Korea, intermarriage between the Japanese and colonized Asians and the influx of the colonized Asians as laborers into mainland Japan, had radically increased since the early 1930s. Under the circumstances, intellectuals and officials in mainland Japan began to become concerned that the boundaries between the colonizer and the colonized were under threat. In particular, Japanese eugenicists, inspired by Nazi Germany's racial hygiene policies and in positions of authority in the newly created Ministry of Health and Welfare, attempted to prove the racial purity of the Japanese while decrying miscegenation between Japanese and the colonized Asians as a form of racial degeneration (Oguma 2002, 216-219). At the time, Furuhata was regional director of the Japanese Society of Race Hygiene (日本民族衛生学会), and was expected by his colleagues to prove Japanese blood purity (Oguma 2002, 225-226). With his eugenicist comrades such as Nagai Hisomu (永井潜, 1876-1957), Furuhata maintained an anti-assimilation position against racial mixture (Chung 2002, 146-147).

In this respect, Furuhata's serological research on the uniqueness of the Japanese was closely linked to the newly strengthened colonial racism in mainland Japan in the 1930s and the 1940s. For this reason, at the peak of the war mobilization of Koreans amid the Pacific War, when the government officially promoted the compulsory assimilation policy, Furuhata still reported that the pure Japanese race in the Japanese archipelago was distinctly separate from other people in the colonized regions of the Empire (Furuhata 1941, 24). Also, his serological research was cited as scientific evidence for Japanese blood purity by anti-assimilationists in mainland Japan (Shiratori 1938, 91-92).

In contrast, in colonial Korea, Satō's serological study of the proximity between Koreans and the Japanese showed a close affinity to the theory of common Japanese and Korean ancestry. While Furuhata's work scientifically assured Japanese superiority and uniqueness under the scheme of colonial racism, Satō's research established scientific grounds for the colonial assimilation policy in favor of Japanese and Korean common ancestry, despite his reticence about the 
political implication of his study. ${ }^{16}$ In fact, his study was quoted by an assimilation propaganda booklet as "modern scientific proof" for the biological affinity between mainland Japanese and Koreans (Kosōrenmei 1943, 46-47).

It was also their different theoretical positions toward Ottenberg's theory that was one of the significant factors that led them to different conclusions. Furuhata disagreed with Ottenberg's hypothesis of the relation between $\mathrm{A}, \mathrm{B}$, and $\mathrm{O}$ blood types as well as the connections between ethnic groups in Asia. Ottenberg suggested that Type O blood was the most primitive blood type and that the other two types were mutations that occurred during the evolution process. On the contrary, Furuhata supposed that the three blood types emerged independently from each other, while maintaining the Hirschfeldian premise of the origins of Type A blood in Europe and Type B in the Pacific-American region (Furuhata 1974, 5-7). Such a position was closely linked to his idea of the role of blood groups in evolution. Furuhata believed that new blood types emerged during the evolutionary process of inferior and simple organisms towards becoming more complex ones (Furuhata and Furuhata 1976, 237-239). This perspective focused on and emphasized distinct types rather than relations among human populations. Within the typological scheme, he tried to divide the Japanese empire's populations into those races that were Japanese and those that were non-Japanese instead of looking for transitions or connections between them.

Meanwhile, Satō accepted Ottenberg's opinion about Koreans as "a transition in their [blood group] proportions towards the Japanese” (Ottenberg 1925, 1393). His fellow physical anthropologists at Keijo convinced him that Koreans were a transitional race between Manchurians and the Japanese. Indeed, Satō's group carried out extensive fieldwork with Keijō's physical anthropologists. In 1935, Ueda Tsunekichi (上田常吉, 1887-1966), a leading physical anthropologist at Keijō, concluded that Koreans residing in the Korean peninsula's central region would belong to the ancestral group of the Japanese in the Japanese archipelago's Kansai region. Furthermore, he found that physical traits of northern Koreans were much closer to Manchurians than they were to southern Koreans (Ueda 1935; 1939). Satō's observation of clinal relations between Manchurians, (northern and southern) Koreans, and the Japanese in blood group distribution, was in accordance with his Keijō colleagues' conclusion based on anthropometric measurements of Koreans. For this reason, Satō accepted Ottenberg's definition of Koreans as a transitional race and extended his interest to use blood groups to study the migrations of ethnic groups.

After the defeat of Japan in the Pacific War, these two serological anthropology projects met very different fates, mainly due to the contrasting implications the two projects might have for the Japanese nation. ${ }^{17}$ After the Allied occupation period from 1945 to 1952, the Japanese government tried to establish a nation-state within the shrunken territory of postwar Japan. Satō's program which was firmly tied into the multi-ethnic empire's assimilation policy and which would have required further fieldwork in former colonial territories to continue - became invalid. This new political context compelled Satō to suspend his research after returning to mainland Japan in 1946. Satō became a professor of forensic medicine at Matsumoto Medical College, and later Dean of Shinshu University School of Medicine, where he focused on clinical forensic medicine, such as autopsy reports, until he died of leukemia in 1959 (Totsuka et al. 1959). Satō's serological anthropology of Koreans remained untold of in his obituaries (Chikumakai 1959, 7). In short, the collapse of the empire brought with it the end of Satō's research.

By contrast, Furuhata's serological anthropology in mainland Japan continued into the postwar period. In 1952, with his protégés at Tōkyō University Medical College, Furuhata moved

\footnotetext{
${ }^{16}$ Here I highlight the complicity of Satō's research with the colonial assimilation policy and do not claim the unilateral relation between a colonial ideology and serological science. Although Jung (2012) more proactively interprets Satō's close relation to the colonial government stating the government's direct financial support, I think that the serologist had other "social" reasons to support the racial affinity between two ethnic groups. First of all, as Oguma (2002) shows, Satō's interpretation was the mainstream view of anthropologists and historians at the time. I explain other reasons why he supported the racial affinity thesis below.

${ }^{17} \mathrm{Nanta}(2008)$ analyzes a similar transition in the field of Japanese physical anthropology before and after WWII.
} 
to Tōkyō Dental and Medical University and catalogued the geographic distribution of newly discovered blood groups in Japan such as Rhesus (Rh), Kidd, and Kell-Cellano systems. Although he and his students adopted the new term "genetic distribution of human populations," he maintained his prewar interest. Even the use of the biochemical race index, which by then most US and UK scientists had dismissed as naïve racial typology, remained unchanged in his postwar research (Furuhata et al. 1954; Boyd 1955, 153-154). In contrast to Satō's project, his research program flourished in the new political situation - the establishment of New Japan as a nationstate in the Japanese archipelago. Furuhata continued his study of racial anthropology based on blood groups as a means of differentiating the Japanese from neighboring groups in East Asia and proving the biological proximity of the Japanese to the European races.

In 1960, Furuhata and his protégé Tanaka Tsutomu (田中任) proposed a new racial classification based on genetic frequencies of blood groups worldwide, although they used the term “ethnic nation" (民族) instead of “race” (人種). ${ }^{18}$ Introducing this classification, Furuhata divided the human species into eight main groups and fourteen subgroups. The Japanese group was in the subgroup “Japanese type" (日本人型), as part of the “West Asian and East European ethnic groups" (西アジア一東ヨーロッパ民族), separating it from “Asian ethnic groups” (アジア州民族) and

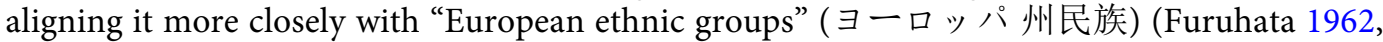
207-214). Furuhata later called his blood-group studies, including serological racial anthropology of the Japanese, “hemo-typology" (血液型学) (Furuhata 1957). In the end, the serological anthropology developed in mainland Japan during the prewar period could be seamlessly integrated into this postwar "hemo-typology" research.

But what happened to blood-group research in Korea after their liberation from Japanese colonialism? What filled the void for Satō and his Japanese coworkers when they returned to Japan? As we shall see, in the course of Korean War, blood-group research in the southern part of Korea would be transformed into transfusion medicine, separate from and replacing colonial serological anthropology.

\section{The death of colonial serological anthropology? "Americanization" of blood group studies in Korea}

In the late 1950s and the early 1960s, Yi Samyŏl and other first-generation scholars of blood-group science in South Korea pursued cataloguing the blood group distribution of Koreans. This section examines how South Korean hematologists began to carry out their blood-group research of Koreans for purposes and motivations that were different from those driving Japanese serological anthropology. As other clinician and medical researcher colleagues at the time, Korean blood scientists were (re-)trained in the U.S. research and clinical institutions and the local research theme drew on their clinical experiences in the U.S. ${ }^{19}$ To understand the transition of bloodgroup studies in South Korea, I will review blood-group research activities there from the end of the Pacific War onwards.

It is evident that after the liberation of Korea from Japan in 1945, Korean medical researchers knew about the serological anthropology of Koreans using the biochemical race index. For instance, in 1946, Ch'oe Tong, who was the sole Korean professor of forensic medicine at the Severance Medical School during the colonial period and who became president of the medical school after the liberation, explained that "blood types can be used for anthropological examination of racial distribution," and "[there is] the race index" (Ch'oe 1946).

The political turmoil and the economic devastation in the second half of the 1940s, however, prevented medical scientists in Korea from conducting any blood-group research, including

\footnotetext{
${ }^{18}$ On the way in which Japanese social scientists developed a racial theory based on the concept of minzoku (民族), see Hoshino (2016).

${ }^{19}$ For the "Americanization" of South Korean cardiology in the 1950s and the 1960s, see DiMoia (2009).
} 


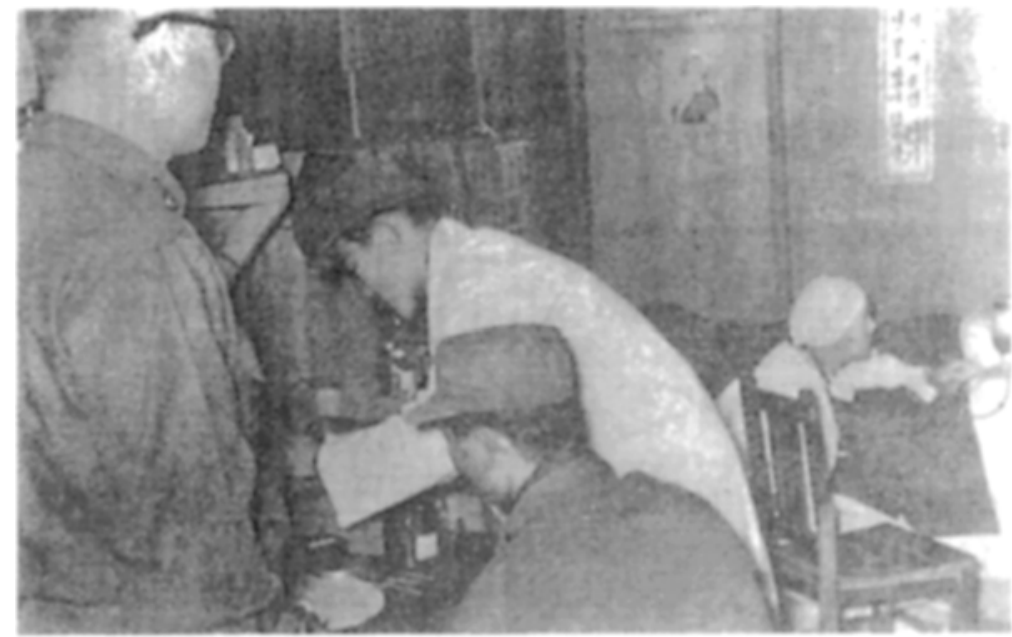

Figure 3. The Republic of Korea Army's Department of Blood Transfusion in 1953 (Source: Kim et al. 1999, 45).

serological anthropology. First of all, since the closing of the Institute of Legal Medicine at Keijō Imperial University Medical School and the establishment of Seoul National University College of Medicine in 1946, there was no longer a research institute for serological anthropology in Korea. Furthermore, research at most medical schools was paralyzed by the political struggle between right and left (Kim 2015). With the scarcity of basic supplies in the aftermath of the Pacific war, blood-typing reagents were also in short supply nationwide (Kim et al. 1999). Lastly, the United States Army Military Government in Korea and later the South Korean government did not allocate much of their budget to basic scientific research. In the government's view, there was no reason to support a survey of blood group distribution in Korea. Instead, they committed to public hygiene programs like cholera prevention (DiMoia 2013). Under these circumstances, there were no medical scientists carrying out blood-group research, despite their knowledge of serological anthropology based on the biochemical race index.

The outbreak of the Korean War on June 25, 1950, made it possible for Koreans to begin bloodgroup studies in a new way, separate from colonial serological anthropology. Wartime necessity for blood transfusions led the US Army and the South Korean Army to establish a blood management infrastructure, including blood banks. During the war, the US Army shipped 340,207 pints of group O, Rh-positive blood to Korea and in 1952, more than 50,000 transfusions were given in Korea (Camp et al. 1973, 38-39). In the last phase of the war, blood transfusions became a necessity in civilian and military field hospitals in South Korea. The South Korean Army and Navy began to establish blood banks to support the demand for blood under the guidance and support of US military forces (Kim et al. 1999, 41). Furthermore, after a truce was reached in 1953, the US Army announced the suspension of the blood supply to Korea and encouraged the Korean government to establish their own national blood management system. As a result, the National Blood Center (renamed the Korean Red Cross Center in 1958) was founded in Seoul in June 1954 (Kim et al. 1999, 41; see Fig. 3).

The first research into the geographical distribution of blood types in South Korea was conducted with the US Army's assistance in 1954. During the war, the $8^{\text {th }}$ US Army's $121^{\text {st }}$ Evacuation Hospital assisted with medical education of the staff of the National Blood Center. Sarkis Sarkisian, a surgeon commander at Saint Alban's U.S. Navy Hospital, New York, was dispatched to Korea to train Korean medical officers and civilian clinicians in blood bank management. Sarkisian encouraged his Korean trainees to survey the main blood groups and Rh types in the South Korean population "to become familiar with whole blood banking procedures" 
(Sarkisian 1956, 1320). His report was the first observational data on the Rh blood type in the Korean population (ibid., 1320-1321).

The U.S. governmental and non-governmental organizations' assistance in medical education in Korea strengthened the Americanization of blood-group research in Korea. A typical example is the Minnesota Project, conducted by the U.S. International Cooperation Administration (ICA). The ICA entered into a contract with the University of Minnesota for faculty education and equipment assistance in engineering, medicine, and public administration for Seoul National University in September 1954, and as a result many medical researchers went to the U.S. to train at the University of Minnesota Medical School (Kim and Hwang 2000, 112-113). In 1955 and 1958, young Korean clinicians could study clinical pathology and hematology at the University of Minnesota Medical School. In addition to ICA's educational aid, the US army assistance program to Korea allowed army surgeons to study blood bank management at the Letterman Army Hospital, San Francisco (Kim 1981, 5-9). Furthermore, several Korean clinicians who obtained medical degrees in Korea during the colonial period moved to the U.S. to learn American medicine.

The first generation of blood-group researchers trained in hematology and blood banking in the U.S. played a crucial role in the establishment of a national blood management system to manage Korea's newly established blood banks. They founded the Korean Society of Hematology and began to collect ABO blood group data from Koreans as a part of their blood bank management (Kim et al. 1999, 49). They also reported the distribution of other blood groups such as MNS, Lewis, Rh, and Kidd systems-based blood samples drawn from Korean donors, and they compared the results with those of other human populations (Wŏn 1959, 1960; Shin and Kim 1960).

Yi Samyŏl's early career shows how Korean blood scientists applied their training in the U.S. to their own country's blood bank management still in its infancy and then moved on to study a survey of blood group distribution. He graduated from the Severance Medical School in 1948 and by the outbreak of the Korean War in 1950 he was working at the National Institute of Health in Korea (國立防疫研究所). After the end of the war, Yi did a residency in clinical pathology and hematology at Montefiore Hospital in Pittsburgh from 1954 to 1958 (Yŏnsedae 2010, 125-127). He had not been interested in blood-group research during the colonial period. However, after he chose hematology as a sub-specialty and became the manager of the blood bank in the last year of his residential work, he began his study of blood-group research, as well as clinical medical treatments associated with blood transfusions (ibid., 137). Indeed, while working for the blood bank in 1957 and 1958, he learned how to perform an exchange transfusion, which is a procedure for the removal of abnormal blood components that involves removing a patient's blood (Rh positive) and replacing it with a donor's (Rh negative) via a catheter. Yi saw that this procedure could be applied in Korea and brought anti-Rh serum for Rh typing back to Korea in 1958.

Upon returning to Korea, he accepted a position as Director of the Department of Clinical Pathology and the blood bank of the Severance Hospital. Starting in the spring of 1959, Yi began Rh typing for blood donors, patients, and medical officers of the blood bank. At the time, the China Medical Board of the Rockefeller Foundation decided to support Severance Hospital, and he benefited from its financial assistance, which he used to purchase anti-Rh and other blood serums. Yi collected data for 154 Rh blood groups for a few months (Yi et al. 1960, 53). During this $\mathrm{Rh}$ blood typing, Yi discovered a pregnant woman who was Rh-negative and was suspected of being at risk of giving birth to a newborn with the hemolytic disease. In May of that year, he performed a successful exchange transfusion to her newborn (ibid.). His research on the blood groups of Koreans was a by-product of such blood bank management and exchange transfusions. In 1960, Yi first reported the distribution of the blood groups of Koreans to justify his clinical recommendations for Rh typing (Lee 1960, 43-44).

In sum, Yi Samyŏl and his hematologist colleagues conducted their blood group research of Koreans drawing on American clinical medicine, but quite separately from the Japanese serologi$\mathrm{cal}$ anthropology that had been conducted in colonial Korea. They had been trained in blood bank management and hematology in the U.S. research institution and began their research keeping 
close relationships with U.S. scientists. Therefore, Satō's serological anthropology program conducted in colonial Korea left almost no traces on the Korean peninsula. As we shall see, a paradoxical situation concerning Korean-Japanese relations in the 1960s, arising as a result of diplomatic normalization with Japan in 1965, would allow Yi Samyŏl to encounter another strand of serological anthropology in mainland Japan and repackage it in nationalistic terms.

\section{"Anti-colonial" revitalization of serological anthropology and its limits}

The so-called April Democratic Movement and anti-Japanese protests in the 1960s led Korean blood-group researchers to reevaluate their blood management practices and blood-group research. In April 1960, workers and students organized a popular uprising against President Syngman Rhee's autocratic regime and Korean police fired on student protesters. ${ }^{20}$ Almost 200 were killed and thousands wounded and citizens brought wounded protesters to university hospitals.

The Severance Hospital was one such hospital that accepted protesters and provided them with blood transfusions. Until the 1960s, paid donors and the U.S. Army troops had been the main suppliers for blood transfusion in hospitals, but the political chaos during the public uprising had resulted in a lack of blood supplies. Under these circumstances, college students and general citizens voluntarily donated their blood for wounded protesters. For example, Yi's blood bank at the Severance Hospital recruited 230 college students in one day to provide the wounded with the blood they needed (Yi 1975.9.). Other blood-group researchers in other hospitals located in Seoul also reported a tremendous amount of voluntary blood donation from the general public during the uprising (P'yŏnjipkuk 1960.4.20.).

This experience led Yi and his hematologist colleagues to think about the "independence of blood transfusion" through institutionalizing a blood donation system in Korea. ${ }^{21}$ After the democratic movement, they fiercely criticized the current blood trade system and its dependence on the supply of Rh-negative blood from the U.S. Army donations. Blood-group researchers achieved independence from the US military forces in terms of blood supplies by implementing a national blood donation system (Yi 1965.5.4). Wŏn Chongtŏk (元鍾德), the director of the Korean Red Cross Center, also warned, "pure blood of our single ethnic Koreans will become mixed with foreign blood by transfusion if we import blood from foreign countries due to the absolute lack of blood supplies," and "thus we have to achieve the independence of blood transfusion" (P'yŏnjipkuk 1963.5.2.).

Yi's interest in "independence" was not limited to blood bank practices, but also extended to blood-group research itself. In fact, being self-sufficient in blood supplies required the domestic development of blood-typing capabilities. If Korean hematologists were not capable of identifying and collecting rare blood types without outside help, they would be unable to offer blood transfusions to meet domestic demands in time. ${ }^{22}$ In this context, while highlighting his own independent blood sample analysis, Yi pointed out that Korean blood group researchers had heavily relied on American hematologists' help in their analysis of Korean blood samples. ${ }^{23}$ Although Yi also

\footnotetext{
${ }^{20}$ For an overview of the April Democratic Movement, see Kim (2000).

${ }^{21}$ Yi positively recalled the April Democratic Movement as the occasion to promote the blood donation system (Yonnsedae 2010, 138). He was also a strong supporter of the Democratic Movement and was critical of the authoritarian regime, at least around the mid-1960s (Yi 1967.4.1.).

${ }^{22}$ Already in 1960, Yi proposed that Korean blood bank authorities should be capable of Rh typing to protect blood transfusion from malpractices (Yi 1960). In 1962, however, the Korean Red Cross Center still did not include Rh typing in its blood banking practices and thus did not collect Rh negative blood. This meant that Korean patients with an Rh negative blood type were reliant on the U.S. army's donations (P'yǒnjipkuk 1962.3.24).

${ }^{23}$ For example, Wŏn Chongtŏk and some hematologists at Seoul National University collaborated with American hematologists at the Minneapolis War Memorial Blood Bank, Minnesota. They collected blood samples from Koreans and later sent them to laboratories in Minnesota via airmail. All sample analysis was conducted by their American counterparts (Won et al. 1960).
} 


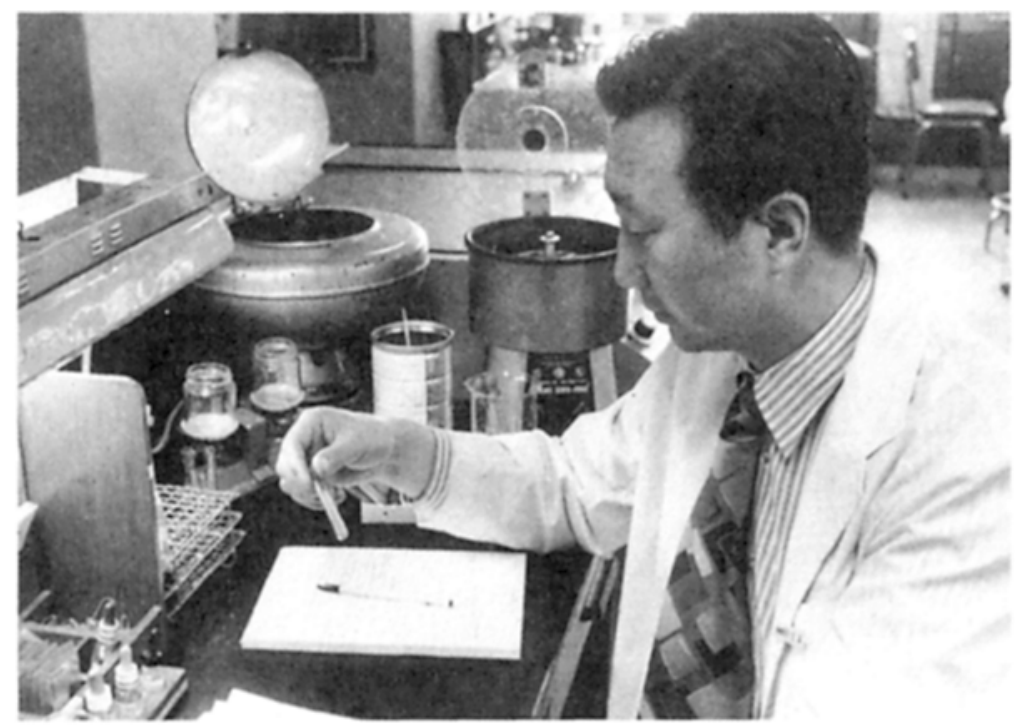

Figure 4. Yi Samyŏl during the 1960s (Source: Yi 1999, 117).

benefited from financial support from the China Medical Board and material support from Tibor J. Greenwalt, the Medical Director at the Milwaukee Blood Center in Milwaukee, he believed that his scientific work had been more independently conducted than that of his Korean colleagues (Yi 1966). Yi proudly declared that his blood-group research on Koreans was valuable because he had carried it out on his own without foreign scientists' support (Chosun Ilbo 1966.08.02). In his view, blood-group researchers in Korea should make an effort to achieve independence in terms of blood-group research as well as blood supplies.

Meanwhile, after the democratic movement, nationalist intellectuals began to seek a national subject in the history of Korea. This academic work included the discovery of a "national culture" (民族文化) and “the subject of national history” (民族史的主體). Furthermore, the diplomatic normalization of relations with Japan in 1965 empowered nationalist intellectuals to promote the postponed decolonization movement, eradicating the Japanese colonial intellectual legacy (Xu 2016, 108-109). Korean intellectuals, as well as the general public, were concerned about the possibility of Japan's re-colonization of Korean culture and history as well as the economy, and asserted a struggle against "cultural, economic invasions of Japanese neocolonialism" (P’yŏnjipkuk 1965a.6.21; 1965b.6.22; Kim 2012, 188). In this context, historians and literary scholars in Korea tried to overcome the colonial perspective in studies of Korean history and culture. They insisted on Korea's autonomous historical development and promoted the idea of the Korean people as the subject of a Korean history that was distinctly separate from Chinese or Japanese history. The denigration of Japanese scholarship on Korea as "colonialist scholarship" (植民史觀) and the assertion of the Korean nation as a sole national subject were trends for Korean scholars who tried to achieve "cultural independence" (文化的獨立) during the 1960s (Kim 2012, 204-207).

Yi Samyŏl understood his reencounter with Japanese scholars in such a nationalistic atmosphere. At the time, medical scientists had begun to resume academic exchanges with Japanese scientists as a result of the diplomatic normalization with Japan in 1965. Yi confronted Furuhata Tanemoto's serological studies using the ABO blood group data of the Japanese and Koreans when he participated in the Eleventh Pacific Scientific Congress held in Tokyo, Japan in 1966 (see Fig. 4). Yi was upset by Furuhata's presentation because he considered Furuhata's work to be a part of colonial serological anthropology justifying assimilation, failing to recognize 
the bifurcated research orientations of the serological anthropology of Koreans during the colonial period (Yi 1969). In fact, Yi experienced forced conscription as a result of the colonial assimilation policy during the Pacific War. Specifically, he entered the Severance Medical School in 1944 to avoid conscription (Yŏnsedae 2010, 94). ${ }^{24}$ His direct observation of forcible conscription based on the colonial assimilation policy led him to believe that Japanese scientific studies of Koreans were just fabricated research to justify an idea of Japanese-Korean unity and thus in turn the assimilation policy (Yi 1981).

In this context, Yi defined Furuhata's blood group research as a Japanese neo-colonial threat that is, a scientific effort to justify the unity of the Japanese and Korean peoples. Furthermore, Yi claimed, “if a nation (民族) wants to become independent (自主獨立), [the nation] should have independence not only in political and economic dimensions but also cultural dimensions particularly scientific independence" (Yi 1969, 57). He argued that only independent research on blood group distribution in Koreans by Korean scientists could assure the status of Koreans in the international community as a scientifically distinct group, different from the Japanese (Yi 1969, 57).

Ironically it was in Furuhata's serological anthropology that Yi found the way to establish Korean biological independence. In fact, regardless of Yi's negative characterization of Furuhata's research as colonial science, he maintained a close academic relationship with this old Japanese academic. ${ }^{25}$ Furuhata was the Convener of the Medical Genetics Part and opened its session at the Pacific Scientific Congress in 1966 (PSA 1965). He invited presenters whose research was related to the distribution of blood groups and serum proteins in the Pacific, including Yi Samyŏl. After the presentation, Furuhata suggested Yi publish his paper in a special issue of The Japanese Journal of Legal Medicine (犯罪学雑誌), and the article appeared in that issue (Lee 1967).

Yi began to cite Furuhata's survey of the blood group distribution of the Japanese and Koreans in his research. He published an article titled "Blood Types of Koreans" in 1969 in which he used Furuhata's research on the geographical distribution of blood groups in the Japanese population, citing the Japanese data as a reference for the Korean case. Also, Yi began to add Furuhata's 1933 research to the literature on the $\mathrm{ABO}$ blood-group data on Koreans when he examined the blood group distribution of Koreans (Yi 1969, 58).

Furthermore, Yi started emphasizing the Koreans' "purity of blood," just as Furuhata's serological anthropology had done for the Japanese. In his 1969 article, Yi used Furuhata's logic to prove Koreans' purity of blood, replacing the position of the Japanese with that of Koreans:

Koreans inherited from Mongolian blood are a racially homogeneous nation and have not been mixed with the blood of neighboring ethnic groups. The Chinese are a mongrel race having blood mixture of the Southern ethnic groups rather than a pure Mongolian blood. The Japanese are also a mixed nation consisting of South Pacific blood, Ainu blood, and some of the Mongolian blood from Korea. I suspect that Mongolians living in

\footnotetext{
${ }^{24}$ In 1942, the Empire of Japan began to conscript Koreans into the Japanese military due to dwindling numbers during the Pacific War. Medical school students were permitted to postpone their military service until they had finished their degrees.

${ }^{25}$ Yi's explicit criticism of Furuhata was unusual compared to his contemporaries in the biomedical fields. During the 1960s, the first and the second-generation biologists - mostly working at Seoul National University - earned their doctoral degree at Japanese universities, where they or their teachers had studied during the colonial period. Medical researchers, particularly those who had graduated from or worked at Seoul National University College of Medicine, a successor institution of the Keijō Imperial University Medical School, supported Japanese scientists and their research in the 1960s. Even Mun Kukchin, the first forensic scientist at the Korean National Institute for Scientific Investigation and a graduate of Seoul National University College of Medicine, was rather proud of his connection with Furuhata (Wŏlgan Chosŏn 2014.09.). It should be noted that Severance graduates like Yi Samyŏl had more freedom to criticize Japanese colonial medicine than Seoul National University graduates, because, except for the last few years, the Severance Medical College was established and managed by the U.S. missionaries during the colonial period.
} 
Mongolia are not racially pure Mongoloid. In this respect, Koreans are the purest, original descendants of Mongolians biologically as well as historically and culturally. A detailed examination of blood groups in Koreans offered several facts to prove the purity of Korean blood. (Yi 1969, 64)

Just as Furuhata claimed the value of serological anthropology for racial classifications in 1935, Yi also emphasized the importance of blood-group research as racial anthropology. He claimed, "the statistical survey of blood types in Koreans is important because it can be precious data for the anthropology and cultural history worldwide, given that Koreans are a pure representative sample of Mongolians" (ibid.). He called his blood-group research "blood typology," a Korean translation of "hemo-typology."

Yi came to concentrate more on racial serology after he identified "mixed-blood children" (混血兒) in Korea. ${ }^{26}$ In 1967, the U.S. Embassy in Korea requested that the Department of Clinical Pathology and the blood bank at the Severance Hospital conduct parentage tests of the children of Korean mothers and U.S. fathers by means of blood groups, because the U.S. Embassy had authorized an immigration priority for Korean women whose children had been fathered by U.S. servicemen. ${ }^{27} \mathrm{Yi}$ and the Severance staff began collecting blood-group data from pregnant Korean women and children of Korean and American parentage starting in 1967. Through the parentage test work conducted over seven years, he began to believe that the increase of "mixed-blood children" could change "the original blood group distribution of Koreans" by those marriages with "pure-blood" Koreans, and thereby influence the blood-typological position of Koreans in the future (Yi 1975, 33). In this respect, he tried to conduct the racial classification of current Koreans and determine the anthropological position of future Koreans from a serological anthropology perspective (ibid., 33-34).

Yi revived the Hirschfelds' biochemical race index and Ottenberg's racial classification based on ABO blood groups from Furuhata's hemo-typology to attempt to place Koreans in their racial classification. He contended that "Koreans are a part of the Indo-Manchurian group," whereas "the Chinese and the Japanese are a part of the Southern Chinese group." For Yi, this scientific evidence showed Koreans to be a racially homogenous population, without the blood mixture of the Chinese and the Japanese. In addition, he calculated Koreans' biochemical race index based on his collection of ABO blood group data in Seoul since 1960, concluding that Koreans are an "Intermediate Type," "much closer to Europeans than Asians." He proudly stated that this blood typology showed "an accordance with anthropological observations that the Korean language is a part of the Ural-Altaic group, and physical features and skulls of Koreans are closest to Caucasians among all Asian ethnic groups" (ibid., 38). He furthermore proposed that the "racial position of Koreans would move to Europeans" because "Caucasian blood would be infused in Korean blood through assimilation of hybrids in Koreans" (ibid.).

Yi Samyŏl's racial serology of Koreans was only made possible by denying the ABO-bloodgroup data produced by serological anthropologists during the colonial period and by reinterpreting Ottenberg's classification. Satō and serologist colleagues divided the blood group distribution of Korea into three local regions (northern, middle, southern) and obtained three different biochemical race indexes in Korea. Yi ignored the regional division of Korea that Japanese serological anthropologists had presumed; instead, he considered his blood-group data obtained from

\footnotetext{
${ }^{26}$ Eunjung Kim (2009) offers an overview of the history of mixed-blood children in South Korea.

${ }^{27}$ The South Korean government legalized prostitution in the Camptowns close to the U.S. military bases in Korea after the Korean War. Although most American troops abandoned their mixed-blood children when leaving Korea, some of them tried to marry Korean women and bring them to the United States. From 1953 to 1968, about 10,200 Korean women migrated to the U.S. by marriage with U.S. citizens. Most of those marriages were between Camptown women and U.S. soldiers (NIKS 2007, 34-42).
} 
residents of Seoul to be representative of all Koreans. Further, Yi selectively used Ottenberg's racial classification and ignored his explanation that the Japanese and the southern Chinese, as part of the "Hunan Type," were closer to Europeans than Koreans, who were instead part of the "IndoManchurian type," along with the northern Chinese (Ottenberg 1925, 1394). For this reason, his effort to make Koreans a pureblood nation was only made possible by cherry-picking parts from old racial anthropology. His prediction that Koreans would be serologically closer to Europeans through the influx of hybrid Caucasian blood was wishful thinking as well, because he intentionally ignored the possibility of intermarriage between non-Caucasians and Koreans. Yi stated elsewhere that his parentage test included those mixed-blood children descended from "Negroes, Honkies, and sometimes Bananas" (Yi 1975.9).

Yi's blood-group research on Koreans was a repackaging of Furuhata's serological anthropology of the Japanese in nationalistic terms. In a 1975 article, Yi cited Furuhata's Stories about Blood Types (血液型の話), published in 1962. Here Furuhata examined the Hirschfelds' and Ottenberg's prewar serological classifications of human races and investigated the serological position of the Japanese among human races. As explained above, Furuhata had classified the Japanese as "the Japanese type," separate from "Asian ethnic groups" and closer to "European ethnic groups" (Furuhata 1962, 207-214). Indeed, Yi's racial serology, which denied biological links with neighboring ethnic groups, emphasized the independent quality of Korean blood and showed its serological proximity to European races, echoing Furuhata's half-century-long project on the Japanese.

Yi's blood science had complicity in colonial racism as well. Just as Furuhata framed the uniqueness of the Japanese in terms of racial hierarchy and the scheme of purity and hybridity, Yi also interpreted his Korean blood-group data in racial terms, newly imbuing the distinction of purity and hybridity with racial superiority and inferiority. Yi praised the blood of Koreans as the purest among the Mongolian race while decrying the mixed blood of the Chinese and the Japanese as a sign of their racial inferiority.

Furthermore, Yi viewed mixed-blood children as a social problem threatening the "pure blood" of Koreans. Yi purposely excluded mixed-blood children of non-white Caucasian and Korean parents in his blood-group research. According to the Ministry of Health and Welfare's census, however, the official number of mixed-blood children in Korea in 1968 was 1,541 and the number of children with a non-white father was 444. Moreover, it was suspected that about 3,000 mixedblood children, especially those who had a black father, may have gone unreported due to harsh racial discrimination on black-mixed children (Kim and Jung 1969, 6). Yi dismissed the presence of children having non-white parentage in his counting of mixed children as potential future Koreans. Yi also frequently represented mixed blood as a symbol of racial inferiority. He contended that Australians and Malaysians were inferior to Koreans despite their greater material affluence because they were "mongrel" (雜種) nations, consisting of mixed-blood people different from pure-blooded Koreans (Yi 1975.10.).

Yi's hatred of mixed blood and his obsession with pure blood were echoed by the mainstream view of the mixed-blood children in Korea at the time. The mixed-blood children of U.S. soldiers and Koreans were regarded as social and physical misfits unfit for Korean nationalism based on the racial purity of Koreans (Hwang 2015). Social analysts argued that their racial heterogeneity would impede the national integration of Koreans (Choug 1966). The Korean government even categorized these children as "disabled people" having "social handicaps" and banished them to the U.S. through adoption (Kim 2017). In this context, Yi intensified the hatred of mixed-blood children, going even further than Furuhata's racial purity argument.

Lastly, instead of criticizing the colonial racism that colonial serological anthropology had contained, Yi internalized and strengthened this racist perspective in his own research and life. When blood groups became a symbol of anti-racial science among population geneticists and anthropologists worldwide, Yi used blood-group data to revitalize colonial racism in the name of anti-colonial nationalism. 


\section{Conclusion}

In this paper, I have traced the origin of Yi Samyŏl's Korean racial serology and its close connection to postcolonial struggles in Korea. Yi began his blood-group research as a part of clinical work related to blood banks and transfusions based on his early training in the U.S., and in the local context of the need for blood transfusion management as a result of the Korean War.

In the mid-1960s, his research turned in the direction of proving ethnic homogeneity, blood purity, and the racial superiority of Koreans based on racial serology. Yi developed the idea of "independence" in blood bank management and blood group research amidst a strong nationalist atmosphere created by the April Democratic Movement in 1960 and the anti-Japanese movement before and after diplomatic normalization with Japan in 1965. When humanist scholars criticized the Japanese scholarship of Korean culture and history as "colonialist scholarship" and decolonized their academic research on Koreans, Yi also cited Furuhata Tanemoto's study of Korean blood as a part of his old serological anthropology research and defined it as colonial science. Yi tried to achieve "scientific independence" from Japan by appropriating Furuhata's colonial serological anthropology and newly promoting the racial serology of Koreans.

After his laboratory was involved with parentage testing of mixed-blood children between U.S. soldiers and Korean women in the late 1960s, Yi advanced his racial serology of Koreans further by highlighting Korean blood purity and degrading blood mixture as a symbol of an inferior race. Although Yi's scientific work was inspired by anti-colonial nationalism and the decolonizing effort during the 1960s, he ultimately shared colonial racism with his colonial enemy and strengthened its racist aspects by amplifying the hatred of blood impurity to justify the Korean people's biological independence.

It is ironic that Yi misconstrued Furuhata's project concerning Japanese uniqueness to be another version of Satō's research project seeking to establish biological unity between the Japanese and Koreans. He criticized Furuhata's serological anthropology for being colonial science justifying assimilation. However, as we have seen, on the contrary, Furuhata's work was in favor of the differentiation strategy of Japanese colonialism. Its exclusive racism based on blood purity meshed perfectly with Yi's aim to establish the Koreans as different from the Japanese. Due to the lack of historical records, it is impossible to know whether Yi continued his misrecognition even after he had begun to co-opt Furuhata's serological anthropology. However, it is evident that this misreading allowed him to locate Furuhata's research in the realm of colonial science while appropriating its content and analysis to frame Koreans as biologically independent.

Although I have illuminated the revitalization of old colonial science in a new post-colonial context, I do not argue a seamless continuity between colonial and postcolonial knowledge regimes without ruptures. Instead, I highlight historical contingencies in Yi's excavation of colonial serological anthropology to reconstruct it as an anti-colonial science in a new political and social context. After the liberation of Korea from Japan, Japanese colonial anthropology in colonial Korea was replaced by American hematology during and after the Korean War. Yi Samyŏl's acceptance and reinvention of colonial serological anthropology for anti-colonial purposes was only possible in the paradoxical situation that the racial purity of Koreans and anti-Japanese sentiment were celebrated in the name of anti-colonialism, while during the mid-1960s academic exchange with Japanese scientists was actively promoted.

Yi's racial serology of Koreans did not impact dramatically on the public discourse in Korea. The second generation of Korean hematologists included Yi's blood typological studies as research on "the unique nature of blood group distributions among Koreans considering social change in the history of Korea" without credible scientific opposition because he was an authority on hematology (Choi et al. 1984). In contrast to academic acceptance of Yi's racial serology, a public response to his research was rare due to his indifference toward the popularization of his ideas. Although Yi regularly wrote a column for a popular monthly magazine Central Monthly (月刊中央), he did not publish any popular books based on his racial serology. 
Despite the unpopularity of Yi's work, similar thoughts to his racial serology were prevalent in popular discourse in the same period. For example, a guidebook of sexual life based on blood type personality theory stated, "the blood group distribution of Koreans shows the median value between Westerners and Orientals," and "it is confident that Koreans have a well-proportioned distribution of blood groups due to their ethnic homogeneity" (Ko 1983, 47). Physical anthropologist Na Sechin at Seoul National University also reinterpreted Satō's colonial research on the blood group distribution of Koreans as scientific proof for Korean ethnic homogeneity (Hyun 2015). Na's reinterpretation of Satō's data was widely circulated in popular books including a government published textbook. It clearly shows that Yi's racial serology resonated with and responded to the widespread belief that Koreans were a pureblood nation and blood science would prove this racial purity.

Finally, this study contributes to the history of blood-group anthropology and race during the early second half of the twentieth century. In Japan and South Korea, serological anthropology flourished in the 1960s, the period remembered for bringing the end of racial serology based on the idea of blood purity (Marks 2012, S164). In contrast to the way in which American scientists used blood groups as a resource to call into question the ontology of race in the context of the U.S. civil rights movement, Japanese and Korean scientists developed racial serology in the context of their postcolonial struggles. This postcoloniality of racial serology in the two countries during the 1960s and the 1970s also encourages historians of science to reconsider the literature on anthropological genetics and race, which predominantly focuses on the postcolonial struggle of genetic research on indigenous people through the Human Genome Diversity Project during the 1990s (Marks 2012, S168). It indicates that the local existence of racial serology should be considered and better investigated for a greater understanding of the postwar history of blood-group anthropology and race.

\section{References}

Bangham, Jenny. 2014. "Blood Groups and Human Groups: Collecting and Calibrating Genetic Data after World War Two." Studies in History and Philosophy of Science Part C: Studies in History and Philosophy of Biological and Biomedical Sciences 47:74-86.

Boaz, Rachel E. 2012. In Search of "Aryan Blood": Serology in Interwar and National Socialist Germany. Budapest, Hungary: Central European University Press.

Boyd, William C. 1955. "Review: The Distribution of the Human Blood Groups. By AE Mourant." American Journal of Physical Anthropology 13:153-158.

Camp, Frank R., Nicholas F. Conte, and Jerry R. Brewer. 1973. Military Blood Banking, 1941-1973: Lessons Learned Applicable to Civil Disasters and Other Considerations. Fort Knox KY: Blood Bank Center, US Army Medical Research Laboratory.

Chikumakai. 1959. “逝去された前信州大学長佐藤武雄博士 [Obituary: Satō Takeo, a Former Dean of Shinsu University].” 千曲会報 [Chikuma Bulletin] 81:7.

Ch'oe, Tong. 1946. “혈액형과 수혈 [Blood Types and Transfusion].” 현 대과학 [Modern Science] 2:36.

Choi, Sungyoub, Sang In Kim, and Han Ik Cho. 1984. “한국인의 혈 액형 유전자 빈도 연구 [A Study on Gene Frequencies of Blood Groups in Koreans].” 대한혈액학회지 [The Korean Journal of Hematology] 19:63-75.

Choug, Yo-Sup. 1966. “한국여성과 사회문제 [Social Problems Facing Korean Women].” 아시아여성연구 [Journal of Asian Women] 5:2-33.

Chung, Yuehtsen Juliette. 2002. Struggle for National Survival: Eugenics in Sino-Japanese Contexts, 1896-1945. New York: Routledge.

de Souza, Vanderlei S., and Ricardo Ventura Santos. 2014. "The Emergence of Human Population Genetics and Narratives about the Formation of the Brazilian Nation (1950-1960)." Studies in History and Philosophy of Science Part C: Studies in History and Philosophy of Biological and Biomedical Sciences 47:97-107.

DiMoia, John. 2009. "From Minnesota to Seoul?: The DeWall Helix Bubble Oxygenerator and Technology Transfer in Open-Heart Surgery, 1955-1965.” Comparative Technology Transfer and Society 7:201-225.

DiMoia, John. 2013. Reconstructing Bodies: Biomedicine, Health, and Nation-Building in South Korea since 1945. Stanford: Stanford University Press. 
Furuhata, Kazutaka, and Tanemoto Furuhata. 1976. 追想古畑種基 [Recollect Furuhata Tanemoto]. Tōkyō: Tama ma shobō.

Furuhata, Tanemoto. 1931. “血液型研究の進展と国際的協力の必要 [The Progress of Blood Group Research and the Necessity for International Cooperation].” 民族衛生 [Race Hygiene] 1:296-304.

Furuhata, Tanemoto. 1933. Value of Blood Grouping in Anthropology. Kanazawa: Hoigaku Kyositu, Kanazawa-Ikadaigaku.

Furuhata, Tanemoto. 1935. “血液型より見たる日本人 [Japanese Viewed from Blood Types].” In 日本民族 [The Japanese Nation], edited by Tokyo Anthropological Society, 83-110. Tōkyō: Iwanami Shōten.

Furuhata, Tanemoto. 1941. “アジア民族の血液型 [Blood Groups of Asian Ethnic Groups].” In 人類学先史学講座: 八 [The Lecture on Anthropology and Prehistoric Research Vol.8], 1-113. Tōkyō: Yūzankaku.

Furuhata, Tanemoto. 1957. 血液型学 [Hemotypology]. Tōkyō: Igakushoin.

Furuhata, Tanemoto. 1962. 血液型の話 [Stories about Blood Types]. Tōkyō: Iwanami Shōten.

Furuhata, Tanemoto. 1974. Development of Haemotypology in Japan. Tōkyō: Tokyo Standard Serums, Ltd.

Furuhata, Tanemoto, Kazumichi Tsuge, Mitsuo Yokoyama, and Toshimasa Ishii. 1954. "Racial Difference of Blood Groups and Blood Types." Proceedings of the Japan Academy 30:405-408.

Furuhata, Tanemoto, and Takayoshi Kishi. 1928. "A Study of the Geographical Distribution of Human Blood-Groups of the Japanese in Various Parts of Japan.” In Proceedings of the Third Pan-Pacific Science Congress, Tokyo, October 30th-November 11th, 1926, edited by the National Council of Japan, 2413-2422, Tokyo: The National Council of Japan.

Furuhata, Tanemoto, and Takayoshi Kishi. 1926. "On the Biochemical Racial-Index of the Japanese in the Hokuriku District (Northern Part of Middle Japan).” The Journal of Immunology 12:83-89.

Furuhata, Tanemoto, Shoei Iseki, and Mutsuo Kitahama. 1966. “Japanese Viewed from the Standpoint of Blood Groups.” In Abstracts of Papers Related with Nutrition, Public Health and Medical Science: Proceedings Volume 8, edited by the Eleventh Pacific Science Congress, 4, Tokyo, Japan: The Eleventh Pacific Science Congress.

Furuhata, Tanemoto, and Koji Ohkura. 1961. "Recent Studies of Human Genetics in Japan. I." Proceedings of the Japan Academy 37:402-407.

Gannett, Lisa, and James Griesemer. 2004. "The ABO Blood Groups: Mapping the History and Geography of Genes in Homo Sapiens." In Classical Genetic Research and Its Legacy: The Mapping Cultures of Twentieth Century Genetics, edited by Hans-Jörg Rheinberger and Jean-Paul Gaudillière, 119-172. New York: Routledge.

Hirschfeld, Ludwik, and Hanna Hirschfeld. 1919. "Serological Differences between the Blood of Different Races: The Result of Researches on the Macedonian Front." The Lancet 194:675-679.

Hoshino, Noriaki. 2016. "Racial Contacts across the Pacific and the Creation of Minzoku in the Japanese Empire." Inter-Asia Cultural Studies 17:186-205.

Hwang, W. Taejin. 2015. "The "Amerasian” Knot: Transpacific Crossings of "GI Babies” from Korea to the United States." In Race and Racism in Modern East Asia: Interactions, Nationalism, Gender and Lineage, edited by Rotem Kowner and Walter Demel Leiden, 503-526. Netherlands: Brill.

Hyun, Jaehwan. 2015. “지방차와 고립한 멘델집단: 두 중심부 과학과 나세진의 혼종적 체질 인류학, 1932-1964 [Sejin Rha's Hybrid Physical Anthropology between Two 'Central' Sciences, 1932-1964].” The Korean Journal for the History of Science 37:345-381.

Hyun, Jaehwan. 2017. "Making Postcolonial Connections: The Role of a Japanese Research Network in the Emergence of Human Genetics in South Korea, 1941-1968.” The Korean Journal for the History of Science 39:293-324.

Hyun, Jaehwan. 2018. “유전적 민족 만들기: 한국의 인류 유전 연구, 민족 정체성, 그리고 초국적 과학 교류, 1926-2009 [The Making of the Genetic Nation: Human Heredity, National Identity, and Transnational Scientific Exchange in South Korea, 1926-2009].” Ph.D. thesis. Seoul National University, Seoul.

Jung, Joon Young. 2012. “피와 인종주의의 식민지 의학: 경성제대 법의학 교실의 혈액형 인류학 [Racism of "Blood" and Colonial Medicine: Blood Group Anthropology Studies at Keijō Imperial University Department of Forensic Medicine]." Korean Journal of Medical History 21:513-550.

Jung, Junho, and Ock-Joo Kim. 2017. “모든 것은 기생충에서 시작되었다’: 1960-1980 년대 한일 기생충 협력 사업과아 시아 네트워크 ['It All Started from Worms': Korea-Japan Parasite Control Cooperation and Asian Network, 1960s-1980s]." Korean Journal of Medical History 27:49-88.

Kang, Etsuko H. 1997. "Kita Sadakichi (1871-1939) on Korea: a Japanese Ethno-Historian and the Annexation of Korea in 1910.” Asian Studies Review 21:41-60.

Keiō Gijuku. 1958. 慶應義塾百年史 [A One Hundred Year History of Keio University]. Tōkyō: Keiōgijuku.

Kevles, Daniel 1995. In the Name of Eugenics: Eugenics and the Use of Human Heredity. Cambridge: Harvard University Press.

Kim, Eunjung. 2009. "Minority Politics in Korea: Disability, Interraciality, and Gender." In Intersectionality and Beyond: Law, Power, and the Politics of Location, edited by Emily Grabham, Davina Cooper, Jane Krishnadas, and Didi Herman, 230-250. Abingdon: Routledge Cavendish.

Kim, Eunjung. 2017. Curative Violence: Rehabilitating Disability, Gender, and Sexuality in Modern Korea. Durham: Duke University Press. 
Kim, Hoi-eun. 2016. "Reauthenticating Race: Na Sejin and the Recycling of Colonial Physical Anthropology in Postcolonial Korea." Journal of Korean Studies 21:449-483.

Kim, Ki Hong. 1981. “한국 임상병리학의 초창기 [Early phase of clinical pathology in Korea].” 대한임상병리학회지 [Korean Journal of Clinical Pathology] 1:5-9.

Kim, Ki Hong, Samuel Y. Yi, and Teuk Yong Kang. 1999. 한국 헌혈 운동사 [The blood donation campaign in Korea]. P'aju: Nanamch'ulp'an.

Kim, Ok-joo, and Sang-ik Hwang. 2000. “The Minnesota Project.” Korean Journal of Medical History 9:112-123.

Kim, Sunhyuk. 2000. The Politics of Democratization in Korea: The Role of Civil Society. Pittsburgh: University of Pittsburgh Press.

Kim, Tae-ho. 2015. “1950년대 한국 과학기술계의 지형도 [The Scientific Community South Korea in the 1950s].” 여성문 학연구 [Feminism and Korean Literature] 29:37-69.

Kim, Won. 2012. “한국적인 것의 전유를 둘러싼 경쟁: 민족증흥, 내재적 발전, 그리고 대중문화의 흔적 [The Competition Concerning Appropriation of 'Things Korean': Revival of Nation, Theory of Indigenous Development and Trace of Popular Culture].” 사회와역사 [Society and History] 93:185-235.

Kim, Young-in, and Ok-Kyoung Jung. 1969. “시설에 수용되어 있는 혼혈아동의 실태 연구 [A Study on the Children of Mixed Parentage in the Children's Institution].” 사회사업 [Social Work] 4:5-24.

Ko, Kiun. 1983. 혈액형 성관리 [Human Sexual Relationship Management Based on Blood Types]. Seoul: Chunganggyoyuksŏgwan.

Kosōrenmei 1943. 御稜威に㝿る朝鮮：内鮮の歴史を顧みて [Korea Revitalized by the Japanese Emperor’s Grace: Recollecting the History of Japanese-Korean Unity]. Keijō: Kokumin sō riki chōsen renmei.

Lee, Samuel Y. [Yi Samyŏl]. 1960. "Various Blood Types in Korean and Related Clinical Problems.” Yonsei Medical Journal 1:40-44.

Lee, Samuel Y. [Yi Samyŏl]. 1965. "Further Analysis of Korean Blood Types.” Yonsei Medical Journal 6:16-25.

Lee, Samuel Y. [Yi Samyŏl]. 1967. “韓国人の各種血液型の研究 [Koreans' Various Blood Types].”犯罪学雑誌 [The Japanese Journal of Legal Medicine] 33:117-127.

Lipphardt, Veronika. 2014. “'Geographical Distribution Patterns of Various Genes”: Genetic Studies of Human Variation after 1945." Studies in History and Philosophy of Science Part C: Studies in History and Philosophy of Biological and Biomedical Sciences 47:50-61.

Marks, Jonathan. 1994. "Blood Will Tell (Won't It?): A Century of Molecular Discourse in Anthropological Systematics." American Journal of Physical Anthropology 94:59-79.

Marks, Jonathan. 1996. "The Legacy of Serological Studies in American Physical Anthropology." History and Philosophy of the Life Sciences 18:345-362.

Marks, Jonathan. 2012. “The Origins of Anthropological Genetics.” Current Anthropology 53:S161-S172.

Matsuda, Kaoru. 1994. 血液型と性格の社会史 [The Social History of Blood Groups and Personality]. Tōkyō: Kawade shobō shinsha.

Mazumdar, Pauline M. H. 1996. "Two Models for Human Genetics: Blood Grouping and Psychiatry in Germany between the World Wars.” Bulletin of the History of Medicine 70:609-657.

Mikanowski, Jacob. 2011. "Dr Hirszfeld's War: Tropical Medicine and the Invention of Sero-Anthropology on the Macedonian Front.” Social History of Medicine 25:103-121.

Miki, Toshiyuki. 1976. “鬼力的な血液型の御講義 [Fascinating Lectures on Blood Groups].” In 追想古畑種基 [Recollect Furuhata Tanemoto], edited by Kazutaka Furuhata and Tanemoto Furuhata, 106-111, Tōkyō: Tama ma shobō.

Mizuno, Hiromi, Aaron S. Moore, and John Dimoia. 2018. Engineering Asia: Technology, Colonial Development, and the Cold War Order. New York: Bloomsbury Publishing.

Mukharji, Projit B. 2014. "From Serosocial to Sanguinary Identities: Caste, Transnational Race Science and the Shifting Metonymies of Blood Group B, India c. 1918-1960.” The Indian Economic and Social History Review 51:143-176.

Nanta, Arnaud. 2008. "Physical Anthropology and the Reconstruction of Japanese Identity in Postcolonial Japan." Social Science Japan Journal 11:29-47.

NIKS (the National Institute of Korean History). 2007. “국제결혼 이민 [International Marriage Migrations].” In 북미주한 인의 역사 [Korean Experience in North America], 34-42. Kwach’ŏn: Kuksa p’yŏnch’an wiwŏnhoe.

Oguma, Eiji. 2002. A Genealogy of Japanese Self-Images. Victoria, Australia: Trans-Pacific Press.

Oh, Tongryong. 2014. "털어놓고 하는 이야기: 대한민국 법의학의 개척자 文國鎭 고려대의대 명예교수 (上) [A Frank Talk: Mun Kukchin, the Pioneer in Forensic Medicine in Korea].” 월간조선 [Wŏlgan Chosŏn], October, pp.307-325.

Ottenberg, Rueben. 1925. "A Classification of Human Races Based on Geographic Distribution of the Blood Groups." Journal of the American Medical Association 84:1393-1395.

P'yŏnjipkuk. 1960. “신음 속에 첫날밤을 새고 [The First Night with Groaning].” 한국일보 [Hankook-Ilbo], 20 April, unpaged.

P'yŏnjipkuk. 1962. “귀한형의 혈 액헌혈 주한미군에서 우리혈 액원에 [The US Army will Donate Rare Blood to Our Blood Banks].” 동아일보 [Dong-a Ilbo], 24 March, p.3.

P'yŏnjipkuk. 1963. “피를 구하려는 피 [Blood Seeking Blood].” 동아일보 [Dong-a Ilbo], 2 May, p.3. 
P’yŏnjipkuk. 1965a. “한일 정식조인에 부치는 우리의 비판, 우리의 자세 [Our Criticism to the Treaty on Basic Relations between Japan and Korea].” 경향신문 [Kyunghyang Shinmun], 21 June, p.3.

P'yŏnjipkuk. 1965b. “조인직전 한일회담 이대로 갈 것인가 (4) [On the Verge of Signing the Korea-Japan Summit (4)]." 동아일보 [Dong-a Ilbo], 22 June, p.1.

P'yŏnjipkuk. 1966. "태평양 과학 회의서 발표될 두 논문 [Two Studies for the Pacific Science Congress]." 조선일보 [Chosun Ilbo], 2 August, unpaged.

PSA (Pacific Science Association). 1965. “11th Congress, Symposium Conveners.” PSA Information Bulletin 17:5-6.

Radin, Joanna. 2014. "Unfolding Epidemiological Stories: How the WHO made Frozen Blood into a Flexible Resource for the Future." Studies in History and Philosophy of Science Part C: Studies in History and Philosophy of Biological and Biomedical Sciences 47:62-73.

Sarkisian, Sarkis S. 1956. “Major Blood Groups in Koreans." United States Armed Forces Medical Journal 7:1320-1322.

Satō, Takeo. 1943. “血液型より見たる東亜諸民族の移動 [The Migration of Ethnic Groups in East Asia from the Serological View].” In 大陸文化研究 続 [A Supplementary Volume to Tairiku Cultural Research]. Tōkyō: Iwanami Shōten.

Satō, Takeo, Jiso Kunifusa, Shoichi Nomura, and Hisashi Hagimori. 1935. “朝鮮人の血液型” [Blood Types of Koreans]. 犯罪学雑誌 [The Japanese Journal of Legal Medicine] 9:42-54.

Schneider, William H. 1995. "Blood Group Research in Great Britain, France, and the United States between the World Wars." American Journal of Physical Anthropology 38:87-114.

Seth, Suman. 2017. "Colonial History and Postcolonial Science Studies.” Radical History Review 127:63-85.

Shin, Gi-Wook. 2006. Ethnic Nationalism in Korea: Genealogy, Politics, and Legacy. Stanford: Stanford University Press.

Shin, Han Su and Eun Bae Kim. 1960. “한국인의 Rh 아형 분석 [The Distribution of Rh Subgroups in Koreans].” 대한산부 인과학회지[Obstetrics \& Gynecology Science] 3:11-26.

Shiratori, Kiyoshi. 1938. “日本民族の起源 [The Origin of the Japanese].” In 日本諸学振興委員会研究報告第四編 (歴史 学) [A Research Report for The Society for the Promotion of Japanese Learning No. 4 (History)], edited by Kō-gaku kyoku, 84-91, Tōkyō: Naikaku insatsu kyoku.

Silverman, Rachel. 2000. "The Blood Group "Fad" in Post-War Racial Anthropology." Kroeber Anthropological Society Papers 84:11-27.

Totsuka, Tadamasa, Zenichiro Ishii, and Tsuyoshi Nasu. 1959. “信州大学学長故佐藤武雄先生の臨床剖検記録 [A Clinical Report Written by the Late Satō Takeo, Dean of Shinshu University].”信州医学雑誌 [The Shinshu Medical Journal] 8:1-6.

Turda, Marius. 2010. “Entangled Traditions of Race: Physical Anthropology in Hungary and Romania, 1900-1940.” Focaal 58:32-46.

Wade, Peter. 2017. Degrees of Mixture, Degrees of Freedom: Genomics, Multiculturalism, and Race in Latin America. Durham: Duke University Press.

Wŏn, Chongtŏk. 1959. "한국인의 타액 S.s 형과 Lewis 혈 액형 [The Distribution of Secretor, Non-secretor and Lewis Blood Group on Koreans].” 대한내과학회지 [The Korean Journal of Medicine] 2:53-59.

Wŏn, Chongtǒk. 1960. “한국인의 Rh-Hr 혈 액형의 빈도 [The Distribution of Rh-Hr blood Types in Koreans].” 대한내과 학회지 [The Korean Journal of Medicine] 3:43-51.

Won, Chong Duk, Han Su Shin, Suk Hwan Kim, Jane Swanson, and G. Albin Matson. 1960. "Distribution of Hereditary Blood Factors among Koreans Residing in Seoul, Korea." American Journal of Physical Anthropology 18:115-124.

Xu, Stella. 2016. Reconstructing Ancient Korean History: The Formation of Korean-ness in the Shadow of History. London: Lexington Books.

Yi, Samyŏl. 1960. "Rh 인자에 의한 태아적아구병에 시행된 한국 최초의 교환수혈 上 [The First Exchange-Transfusion in Korea on Rh Sensitized Erythroblastosis Fetalis 1].” 최신의학[The New Medical Journal] 3:35-39.

Yi, Samyŏl. 1965. “가족공혈 운동을 제창하면서 [The Announcement about the Family Blood Donation Movement]." 동아 일보 [Dong-a Ilbo], 4 May, p.6.

Yi, Samyŏl. 1966. "Diego factor 등 수종 혈액형에 관한 조사 [Investigation on Diego Factor and a Few Other Blood Types among Koreans]." 대한혈액학회지 [The Korean Journal of Hematology] 1:45-52.

Yi, Samyŏl. 1967. “4월의 문턱에 서서 [Entering April].” 동아일보 [Dong-a Ilbo] 1 April, p.5.

Yi, Samyŏl. 1969. “한국인의 혈 액형 [Blood Types of Koreans].” 한국의과학 [The Official Journal of Research Institute of Medical Science of Korea] 1:57-66.

Yi, Samyŏl. 1975. "Caucasians 과의 혼혈이 한국인의 혈액형에 끼치는 문제점 [Possible Problems on the BloodTypological Studies of Koreans Caused by Inter-Racial Marriages with Caucasians].” 대한혈액학회지 [The Korean Journal of Hematology] 10:33-39.

Yi, Samyŏl. 1975. “과연 내 자식일까? [Are They My Children?].” 월간중앙 [Wŏlgan Jungang], September.

Yi, Samyŏl. 1975. “우리도 잘 살 수 있다 [We Can Also Live Rich]." 월간중앙 [Wŏlgan Jungang], October.

Yi, Samyŏl. 1981. "원호의 달에 생각한다 [A Thought on Memorial Month]." 월간 세브란스 [Wŏlgan Sepŭransŭ]. 
Yi, Samyŏl. 1999. 한들(일야) 회고록: 내 잔이 넘치나이다 제2편 [The Recollection of Handŭl(Irya): My Cup OverflowsVolume 2]. Sŏul: Ihwajŏngmirinswae.

Yi, Samyŏl, Chaesŏk. Yi, and Kyŏngil Yi. 1960. “한국인의 Rh-Hr, Kell, Duffy, MN 및 ABO System 과 그 임상적 의의 [The Rh-Hr, Kell, Duffy, MN and ABO Blood Groups in Koreans and the Clinical Significance].” 최신의학 [The New Medical Journal] 3:49-57.

Yŏnsedae. 2010. “한국 진단검사의학의 개척자, 이삼열 [Samuel Y. Lee, the Pioneer in Laboratory Medicine].” 연세의사학 [Yonsei Journal of Medical History] 13:89-141.

Jaehwan Hyun is a postdoctoral fellow at the Department III, Max Planck Institute for the History of Science. He received a $\mathrm{PhD}$ in 2018 at Seoul National University, with a dissertation examining the role of geopolitics and transnational collaboration in the mutual constitution of human genetics and national identity in Korea from 1926 to 2009. Now Jaehwan focuses on how the International Biological Program (1964-1974) and related scientific cooperative projects were entangled with the postcolonial nation-building of Japan and South Korea, global environmentalism, and the U.S. military interventions across the Pacific. In particular, he looks at how anthropologists and ecologists "naturalize" borderlands and border peoples in the two countries.

Cite this article: Hyun, Jaehwan. 2019. "Blood Purity and Scientific Independence: Blood Science and Postcolonial Struggles in Korea, 1926-1975,” Science in Context 32:239-260. doi:10.1017/S0269889719000231 